\title{
右顎下部に認めた異所性甲状腺腫例
}

\author{
藤垣 聖雄・浅野幸一郎・加藤 雅也 \\ 澤井 薰夫・伊藤 八次・宮田 英雄
}

\section{A Case of Ectopic Thyroid Gland in the Submandibular Region}

\author{
Masao Fujigaki, Koichiro Asano, Masaya Kato, Shigeo Sawai, \\ Yatsuji Ito and Hideo Miyata \\ (Gifu University)
}

\begin{abstract}
We report a rare case of an ectopic thyroid gland that developed in the right submandibular region. The patient was a 65 -year-old female. She complained of a mass $(4.0 \times 3.0 \mathrm{~cm})$ in her neck, and was admitted to our hospital. An ultrasonic scan, CT scan and fine needle aspiration biopsy were performed before the resection. Results of these examinations did not give diagnostic information. After the resection, the histological appearance showed an adenomatous goiter. This could not be clinically distinguished from a tumor of the submandibular gland. Ectopic thyroid tissue should be considered in the differential diagnosis of a mass in the submandibular portion.
\end{abstract}

Key words : ectopic thyroid gland, submandibular region, adenomatous goiter

はじめに

異所性甲状腺は甲状腺原基の下降障害により生じ，そ の発生部位は甲状舌管の存在した部位, すなわち頸部正 中に沿って出現するのが普通で, 舌根部や喉頭部拉よび 気管周囲の組織中に見い出されることが多い，最近，右 顎下部に認めた異所性甲状腺腫の 1 例を経験したので報 告する.

\section{症例}

症例 : 65歳, 女性.

主訴 : 右靧下部腫瘤.

既往歷 : 高脂血症.

家族歷：特記すべきことなし。

現病歴 : 平成 10 年 7 月初旬頃, 感冒症状にて近医内科 受診し，右顎下部腫瘤を指摘された. 本人はその時まで 自覚していなかった，自発痛，圧痛などの自覚症状がな いためしばらく様子をみていたが，指摘されてから腫瘤 が気になり，近医耳鼻咽喉科を受診した。右䫣下腺腫瘍
を疑われ，手術治療目的で当科を紹介され，平成 10 年 9 月 7 日入院となった.

局所所見：右䋶下部に大きさ $4.0 \times 3.0 \mathrm{~cm}$, 表面平滑, 弾性軟で可動性良好の腫瘤を認めた。自発痛, 圧痛は認 めなかった(図 1)。頸部のリンパ節は触知しなかった.

超音波エコ一所見：境界明瞭で，内部はやや不均一な 充実性の腫瘤を認めた、また後方ェコーの増強を認めた (図 2 ).な拈同部からの FNA では, class I であった.

頸部 CT 所見：単純 CT (図 3, 左)で, 右龥下部に境 界明瞭で辺縁は整, 内部は一部不均一の腫瘤を認めた. 造影 CT (図 3, 右)では陰影はやや増強された。

以上より右顎下腺腫瘍, 悪性腫瘍のリンパ節転移も考 えられるため, 診断目的もかねて平成 10 年 9 月 9 日, 全 身麻酔下に摘出術を施行した。

手術所見 : 腫瘤は罰二腹筋前腹, 䫇舌骨筋を外方に圧 排するように位置し，周囲との癒着はなかった．被膜は 非常に血流に富んでいたため, 適宜止血を行いながら剥 離し摘出した．深部では腫瘤は舌骨の右側に接するよう 


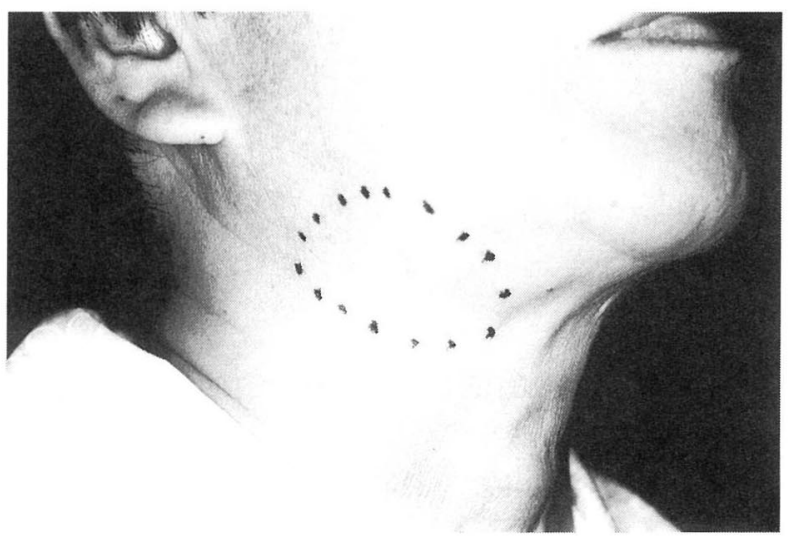

図 1 右顎下部に弾性軟で可動性良好な腫瘤を認める.

に位置していた，副甲状腺おるび栄湌動脈は確認できな かった．摘出後の術中の迅速病理では腺腫様甲状腺腫と いら結果であった。肉眼的には甲状腺方向への組織の連 絡は認めなかった。
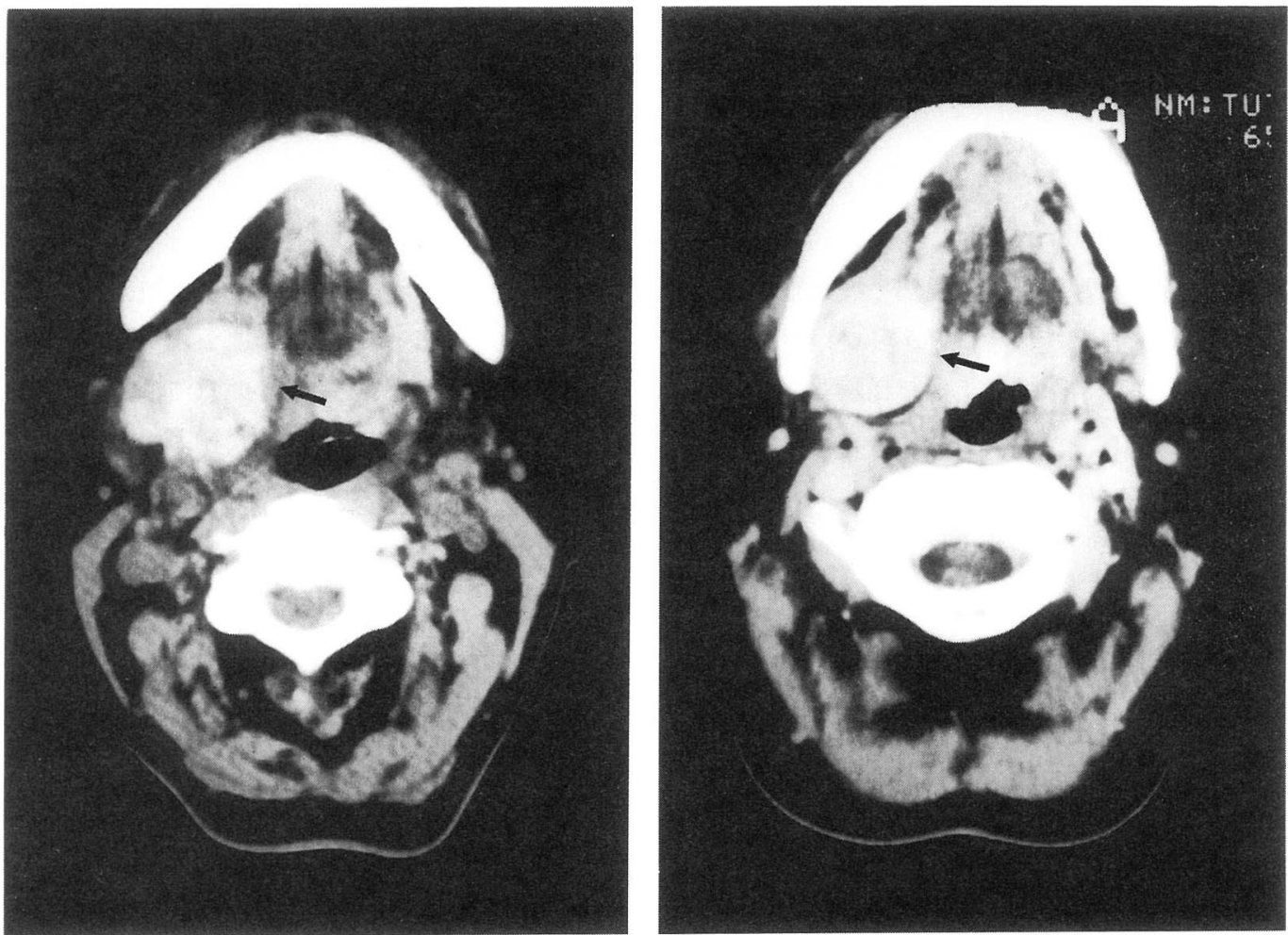

図 3 CT 所見

（左）単純：境界明瞭で辺縁は整，内部は不均一な腫瘤を認める(矢印).

（右）造影：腫瘤はややェンハンスされている(知印).
摘出標本 : 大ささは $5.0 \times 4.0 \times 3.0 \mathrm{~cm}$, 表面平滑, 弾性軟であった．色調は赤褐色であった．割面をいれる と，内部以充実性であり結節性構造を認めた(図 4 ). 

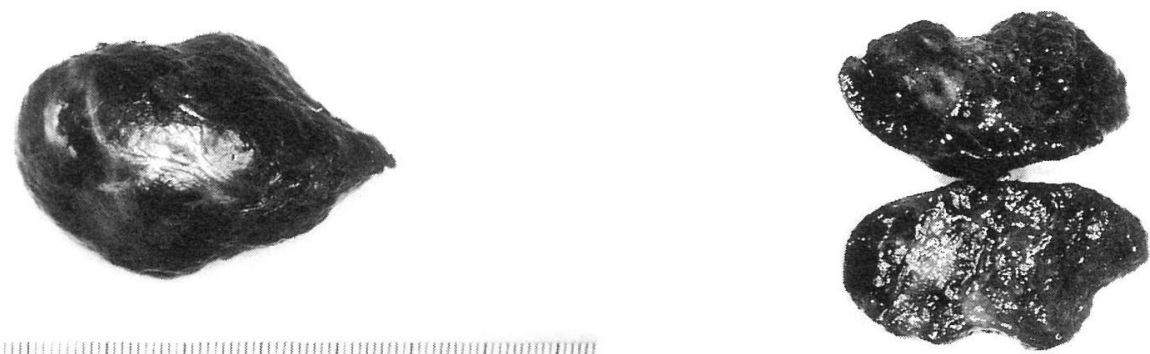

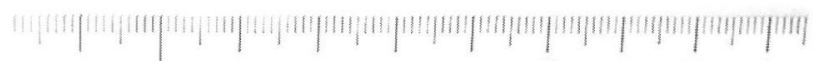

9

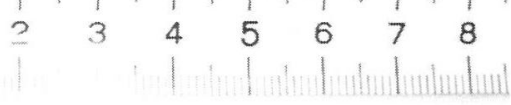

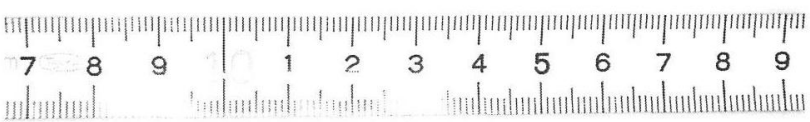

図 4 摘出標本

（左）腫瘤は $5.0 \times 4.0 \times 3.0 \mathrm{~cm}$ の大きさで色調は赤褐色, 表面は平滑.

(右) 割面は内部は充実性で結節構造が認められる.

病理組織学的所見：コロイドを含さ大小の濾胞が結節 性に增殖している像で診断は術中迅速病理と同じく腺腫 様甲状腺腫であった。連続切片により詳細に検討したが， 悪性像は認められなかった(図 5 ).

術後経過：血液検査では術後 1 日目から TSH が 13.30 $\mu \mathrm{U} / \mathrm{ml}, 5$ 日目には $65.34 \mu \mathrm{U} / \mathrm{ml}$ (正常值 : 0.35〜3.73) と上昇してきたため, 術後 7 日目からレボチロキシンナ トリウム $(50 \mathrm{mg}) 4$ 錠の朝 1 回投与を開始した。な拈 清 $\mathrm{Ca}, \mathrm{PTH}$ は正常值であった。術後の甲状腺シンチグ ラフィーでは $99 \mathrm{~m} \mathrm{Tc}$ で正常部位に集積は認められなかっ たが，舌根部，舌下部に集積が認められ，異所性甲状腺 の存在が疑われた(図 6 )。 Tl シンチグラフィーでは早 相期, 後相期とも明らかな異常集積は認めなかった。 ${ }^{123 I}$

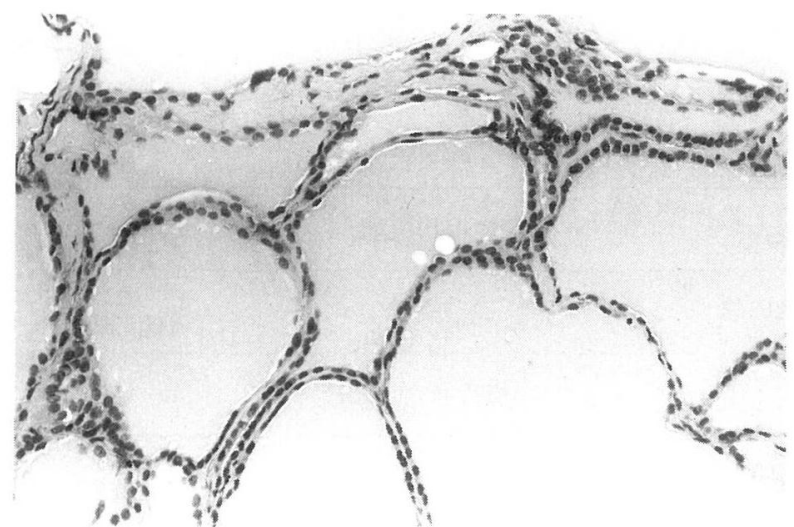

図 5 病理組織標本 $(\mathrm{HE}$ 染色 $\times 100)$ コロイドを含さ大小の濾胞が結節性に増殖している。

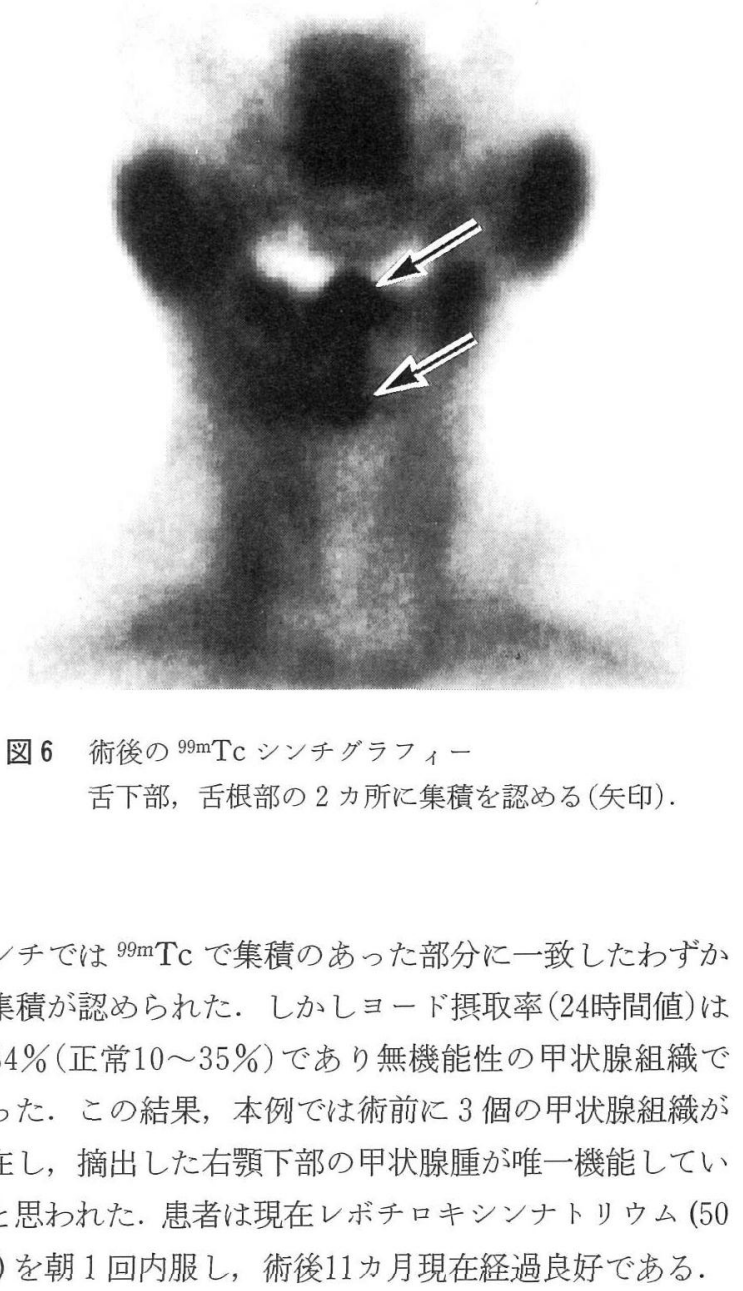




\section{考察}

異所性甲状腺の存在部位は甲状腺の発生過程と深いか かわりを有し, 甲状舌管に沿った部位に出現するのが普 通で, 舌根部や喉頭部特よび気管周囲の組織中に見い出 されることが多い.なかでも舌根部に発生するものが最 も多く，45\%を占めているといわれている11. しかしま れに縦隔内にる認められ, 臨床的に縦隔(内) 甲状腺ある いは絽隔甲状腺腫として発見される。

今回の症例は甲状腺原基の発育過程で発育障害, 下降 障害が生じ, 舌下部, 舌根部に甲状腺組織を残しながら 下降し，一部が正中から右方へずれて右钼下部に留まっ たと推察した。一部が右方へ移動した理由は不明である. Kaplan $5^{2)}$ は, 甲状腺原基の下降障害は, 発育不全の ため二次的に起こるとしている. 本来あるべき位置に正 常な甲状腺組織がなく, 異所性甲状腺が顎下部に認めら れた症例はわれわれが渉猟し得た限りでは過去に本邦に おいて報告がなく，欧米では 7 例の報告3) 9) があり，自 験例を含めて 8 例になる(表 1 )。 また本邦に沶いて, 安

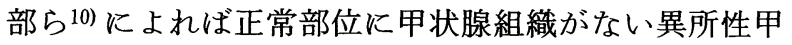
状腺の場合, 甲状腺組織は 1 個ないし 2 個としている. しかし高橋ら ${ }^{11)}$ は 3 個存在した異所性甲状腺の 1 例を 報告しているので自験例と合わせると 2 例になる.

異所性甲状腺の発症年踰は佐藤ら ${ }^{12)}$ の統計では 0 69歳まで幅広く分布しているが10歳代が48例と最も多く,
次いで $0 \sim 9$ 歳が 43 例で, 平均年齢は 18.9 歳である. 男 女比は $1: 5$ であったと報告している. 今回の症例は65 歳の女性で高龄であった.

異所性甲状腺の初発症状としては嚥下障害, 発声困難, 呼吸困難などが多く報告13)されているが，橋本ら ${ }^{14)}$ は 甲状腺機能正常例では舌根部腫瘤, 咽頭異和感が, 甲状 腺機能低下例では成長障害, 高 TSH 血症などが多いと している. 異所性甲状腺と先天性甲状腺機能低下症の関 係についてみると先天性甲状腺機能低下症の $63.6 \%$ 亿異 所性甲状腺がみられたとの報告15) もあり，また Katz $ら^{16)}$ ，Montgomery ${ }^{1718)}$ はそれぞれ舌根甲状腺症例の10 \%，15\%に甲状腺機能低下症がみられたという．今回の 症例では65歳であったが，甲状腺機能低下を示すような 症状や他の自覚症状もなかった。

治療に関しては，一般的に正常部位に甲状腺組織が存 在し，側頸部などに甲状腺組織が迷入する場合のほとん どは甲状腺癌のリンパ節転移といわれ，この場合は側頸 部の甲状腺組織は摘出すべきで，さらに正常部位の甲状 腺の慎重な検索, 治療が必要となる。しかし今回のよう に正常部位に甲状腺組織がない場合は，単なる甲状腺の 下降不全によると考兄られるため，悪性腫瘍である可能 性は少ない，異所性甲状腺の組織像は一般的に正常甲状 腺か腺腫様な組織像であることが多く，乙かも悪性化の 頻度は固有位置のものより少ないといわれている10)。乙

表 1 頻下部に認められた異所性甲状腺の報告例

\begin{tabular}{|c|c|c|c|c|c|c|}
\hline 症例 & 報 告 者 & & 症例 & 部位 & 病理組織 & 正常甲状腺 \\
\hline 1 & Helidonis $5^{3)}$ & 1980 & 30歳 女性 & $\begin{array}{l}\text { 左頧下部 } \\
\text { (部) }\end{array}$ & びまん性コロイド様甲状腺腫 & 無 \\
\hline 2 & Alsop $5^{4)}$ & 1986 & 61歳 女性 & $\begin{array}{l}\text { 右顎下部 } \\
\text { (舌根部) }\end{array}$ & 濾胞状甲状腺腫 & 無 \\
\hline 3 & Aguirre $5^{5)}$ & 1991 & 47歳 女性 & 左顎下部 & コロイド様甲状腺腫 & 無 \\
\hline 4 & Morgan $5^{6)}$ & 1995 & 50歳 女性 & $\begin{array}{l}\text { 右顎下部 } \\
\text { (根部) }\end{array}$ & 結節性甲状腺腫 & 無 \\
\hline 5 & Sambola-Cabrer $5^{7)}$ & 1996 & 34歳 女性 & 右顎下部 & 過形成 & （低形成） \\
\hline 6 & Sironi $5^{8)}$ & 1996 & 45歳 女性 & $\begin{array}{l}\text { 右䫁下部 } \\
\text { 左䫟下部 }\end{array}$ & 施行せず & 無 \\
\hline 7 & Temmel $5^{9)}$ & 1998 & 18歳 女性 & 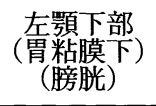 & 施行せず & 無 \\
\hline 8 & 自験例 & 1998 & 65歳 女性 & $\begin{array}{l}\text { 右頡下部 } \\
\text { 舌下部 } \\
\text { 舌根部 }\end{array}$ & 腺腫様甲状腺腫 & 無 \\
\hline
\end{tabular}


かし欧米では悪性化した症例は21例の報告19)があり， 悪性化の頻度は約 100 例中 1 例とされている20). 悪性化 については, 寺師ら ${ }^{21)}$ は, 未発達の異所性甲状腺が長 期間の TSH の過剰刺激のため腺腫様の変化をとり，ひ いては悪性化をもたらすと考えることができると述べて いる. 自験例の病理組織は腺腫様甲状腺腫であり, 表 1 で示した症例 1，3 でュロイド様甲状腺腫, 症例 2 で濾 胞状甲状腺腫, 症例 4 で結節性甲状腺腫, 症例 5 で過形 成といら結果で, 組織検査の記載のあった症例 6 例(症 例 $1 \sim 5,8)$ 中 5 例で腺腫様の変化をさたしていた.こ れらの症例に执いては長期間の TSH の過剰刺激状態に あった可能性はある.

Turcot ${ }^{22)}$, Wilkins ${ }^{23)}$ は悪性化の可能性がある限り, 異所性甲状腺は摘出した方が良いとしている. しかし， それが唯一の機能性甲状腺組織の場合は, 摘出により甲 状腺機能低下は必発であるので, 摘出するか保存的に経 過をみるか，慎重に検討しなければならない，今回の症 例では, 術前の画像所見などから第一に右顎下腺腫瘍を 疑ったが，異所性甲状腺を疑らことはなかった. 表 1 で 示した自験例を除く組織検査の記載のあった 5 例におい ても，1例(症例 5 ) で術前の FNA で甲状腺組織が嶷わ れ, 摘出とならなかったが他の 4 例では摘出後にはじめ て甲状腺組織であることがわかった．

今後はきわめてまれであるが，顎下部にも異所性甲状 腺が存在し得ることを念頭におく必要があり, 頸部腫瘤 の術前診断がはっきりしない場合, 超音波ェコー, CT などを施行した際, 常に甲状腺の存在を確認するなどの 配慮をすべさと考えた.

$$
\text { まとめ }
$$

1. 右顎下部に認められた異所性甲状腺腫の 1 例を報 告した.

2. 顎下部腫瘤ではきわめてまれであるが，異所性甲 状腺腫である場合もあり, 念頭に打く必要があると思わ れた。

本論文の要旨は第61回耳鼻咽喉科臨床学会 (平成11年, 大分) にてロ演した.

\section{参考文献}

1 ）加藤良平, 矢川寛一: 迷入甲状腺および稀な甲状腺腫瘍. 内分泌外科 $4: 244 \sim 249,1987$.
2) Kaplan M, Kauli R, Lubin E, et al : Ectopic thyroid gland; a clinical study of 30 childlen and review. J Pediatr 92 : 205 209, 1978.

3 ) Helidonis E, Dokianakis G, Papazoglou G, et al : Ectopic thyroid gland in the submandibular region. J Laryngol Otol $94: 219 \sim 224,1980$.

4) Alsop JE, Yerbury PJ, O’Donnel PJ, et al : Signet ring cell microfollicular adenoma arising in a nodular ectopic thyroid; a case report. Oral Pathol $15: 518 \sim 519,1986$.

5 ) Aguirre A, de la Pierda M, Ruiz R, et al : Ectopic thyroid tissue in the submandibular region. Oral Surg Oral Med Oral Pathol $71: 73 \sim 76,1991$.

6 ) Morgan NJ, Emberton P and Barton RPE : The importance of thyroid scanning in neck lumps ; a case report of ectopic tissue in the submandibular region. J Laryngol Otol $109: 674 \sim 676,1995$.

7 ) Smbola-Cabrer I, Fernandes-Real JM, Ricart W, et al : Ectopic thyroid tissue presenting as a submandibular mass. Head Neck $18: 87 \sim 90,1996$.

8 ) Sironi M, Assi A, Andruccioli M, et al : Submandibular ectopic thyroid gland. Clin Nuclr Med $21: 585,1996$.

9 ) Temmel AFP, Baumgartner WD, Steiner E, et al : Ectopic thyroid gland simulating a submandibular tumor. Am J Otolaryngol $19: 342 \sim 344,1998$.

10）安部治彦, 小林武夫 : 舌根部と舌下部に発生した異所性甲 状腺の 1 例. 耳喉 $54: 357 \sim 364,1982$.

11）高橋 姿, 川名正博, 五十嵐秀一, 他：異所性甲状腺を示 した 2 症例. 耳喉 $54: 637 \sim 640,1985$.

12）佐藤言葉, 田川俊郎, 中川英俊, 他 : 舌甲状腺の 1 症例な らびにその文献的考察. 日口外誌 $31: 754 \sim 759,1985$.

13) Dudley JW and Willard P : Lingual thyroid ; review, case reports, and therapeutic guidelines. Ann Otol Rhinol Laryngol $86: 841 \sim 848,1977$.

14）橋本禎介, 久保敦司, 橋本省三 : 甲状腺シンチグラフィに より発見された異所性甲状腺の 20 例. 臨放 $33: 357 \sim 363$, 1988.

15) Mamdouh $G$ : The role of thyroid dysgenesis and maldescent in the etiology of sporadic cretinism. J Pediatr 60 : $830 \sim 835,1962$.

16) Katz $\mathrm{AD}$ and Zager WJ : The lingual thyroid ; its diagnosis and treatment. Arch Surg $102: 582 \sim 585,1971$.

17) Montgomery ML : Lingual thyroid; a comprehensive review. West J Surg Obstet Gynec $43: 661 \sim 669,1935$.

18) Montgomery $\mathrm{ML}$ : Lingual thyroid; a comprehensive review. West J Surg Obstet Gynec $44: 54 \sim 62,122 \sim$ 128, 189 195, 237 247, 1936.

19) Fish J, Robert M, Moore RM, et al : Ectopic thyroid tissue and ectopic thyroid carcinoma; a review of the literature 
and report of a case. Ann Surg $157: 212 \sim 222,1963$.

20) Jarvis JF : Lingual thyroid; a report of three cases and discussion. S Afr Med J 43 : 8 12, 1969.

21）寺師浩人, 大原義雄, 林鐘 学, 他：異所性甲状腺の存在 が疑われた正中頸震胞の経験. 形成外科 $31: 948 \sim 954$, 1988.

22) Turcot J : Lingual and hyoid thyroid. Am J Surg 104 : $677 \sim 681,1962$.

23) Ward GE, Cantrell JR and Alann WB : Lingual and other aberrant thyroids. The Diagnosis and Treatment of Endocrine Disorders in Childhood and Adolescence 2nd ed (ed by Wilkins L). pp 152, Charles C Thomas, Springfield, Illinosis, 1952.

(原稿受付 : 平成 12 年 3 月 6 日 原稿採択 : 平成12年 4 月 19 日 別刷請求先 : 藤垣聖雄 于500-8705 岐阜市司町40

岐阜大学医学部耳鼻咽喉科学教室) 